\title{
Factors related to duration of hospitalization and death in premature newborns*
}

\author{
Fatores relacionados ao tempo de hospitalização e óbito de recém-nascidos prematuros \\ Factores relacionados con la duración de la estancia hospitalaria \\ y la defunción de los recién nacidos prematuros
}

How to cite this article:

Silva RMM, Zilly A, Ferreira H, Pancieri L, Pina JC, Mello DF. Factors related to duration of hospitalization and death in premature newborns. Rev Esc Enferm USP. 2021;55:e03704. doi: https://doi.org/10.1590/S1980-220X2019034103704

\section{Rosane Meire Munhak da Silva ${ }^{1}$ \\ Adriana Zilly ${ }^{1}$ \\ Helder Ferreira ${ }^{1}$ \\ Letícia Pancieri² \\ Juliana Coelho Pina ${ }^{3}$ \\ Débora Falleiros de Mello}

\footnotetext{
* Extracted from the thesis: "O cuidado de crianças prematuras em região de fronteira: necessidades essenciais e especiais de saúde”, Escola de Enfermagem de Ribeirão Preto, Universidade de São Paulo, 2019.

1 Universidade Estadual do Oeste do Paraná, Campus de Foz do Iguaçu, Foz do Iguaçu, PR, Brazil.

2 Universidade de São Paulo, Escola de Enfermagem de Ribeirão Preto, Departamento de Enfermagem Materno e Infantil e Saúde Pública, Ribeirão Preto, SP, Brazil.

3 Universidade Federal de Santa

Catarina. Departamento de Enfermagem,

Florianópolis, SC, Brazil.
}

\begin{abstract}
Objective: To analyze factors related to prolonged hospitalization and death in premature newborns in a border region. Method: Cross-sectional study, with retrospective data collection, which analyzed 951 medical records of premature newborns hospitalized between 2013 and 2017. The independent variables were maternal age, nationality, prenatal appointments, maternal intercurrences, gestational age, weight at birth, Apgar, complications; the dependent variables were days of hospitalization, discharge, death, and transference. The tests Pearson Chi-squared and Fisher's Exact were employed. Results: Premature birth amounted to $10.3 \%$; out of these, $43.3 \%$ were hospitalized. The prevalence of mortality was $21.3 \%$. Few prenatal appointments, maternal intercurrences, low fifth minute Apgar, and the baby's health complications increased days of hospitalization. Lower weight and gestational age, low Apgar and complications with the baby increased death. Conclusion: Understanding hospitalization aspects enabled the identification of factors that lead to complications to the premature newborn, which are relevant to efforts to overcome unfavorable outcomes and face challenges posed by the sequels throughout life. The integration between countries and their borders is a notorious condition to accelerate care processes and promote better outcomes.
\end{abstract}

DESCRIPTORS

Infant, Premature; Hospitalization; Death; Neonatal Nursing; Border Health. 


\section{INTRODUCTION}

Prematurity is present in circa 15 million births per year worldwide, and around one million of these children die due to complications of premature birth ${ }^{(1-2)}$. In Brazil, approximately 345,000 premature children are born per year and the complications due to prematurity constitute the leading cause of death among children under five years old ${ }^{(3)}$.

Mortality in the neonatal period, a challenge for health services, is strongly related to low Apgar scores at birth, prematurity, and low weight, indicating the need for a higher integration of prenatal services and neonatal care ${ }^{(4)}$. During the premature child's hospitalization, the presence of complications may increase the risk of death. Sepsis is among the main causes of morbimortality, with a difficult diagnosis by reason of the first clinical signs being minimal and fastevolving ${ }^{(5)}$. Studies also emphasize complications involving the respiratory, cardiac, and neurologic systems ${ }^{(5-7)}$. Cerebral and lung hemorrhagic changes are among the most severe complications that lead to irreversible sequels or to the premature newborn's death ${ }^{(7-9)}$.

In addition, adverse situations due to the diverse disorders, clinical interventions, and institutional work processes in premature care, especially for babies requiring prolonged hospitalization, result in a higher number of children who require complex care and in the evolution of chronic problems which influence growth and development ${ }^{(10-11)}$. The long-term cost of children who are hospitalized for a long time, away from their families, are hardly measurable; this implies the need to increase family interaction in the hospital and the responsibility for investing in health promotion, prevention of aggravation, and recovery ${ }^{(3)}$.

To evaluate in depth the mortality of premature newborns in a border region, this study's location, it is fundamental to consider the quality of prenatal care, labor care, childbirth care, and the physical and material resources available, in addition to the work process of health teams. In this process, nurses may be protagonists in actions for prenatal and birth care. However, a study points the ambiguity of the limited offer of actions for the pregnancy of foreign women and the attribution of providing urgency care during childbirth ${ }^{(12)}$.

The complexity of border municipalities lies on the constant populational movement in search for healthcare; in these, the requirement of presenting residency proof in the country for non-urgent care results in a lack of actions for health promotion and prevention of aggravation. Such dynamic provokes an overcharge in healthcare, making it time-consuming and little remedial, considering the demand by foreigners and Brazilians who live in neighboring countries ${ }^{(12-13)}$. This overcharge leads public budgets to deficit since funding is calculated by resident population and the absence of health programs and the economic and social fragility of neighboring countries hinders public management. Thus, the scarce investment in actions for health promotion ${ }^{(13)}$, specially for vulnerable segments, such as premature care, results in unfavorable outcomes, i.e., prolonged hospitalization and death.

In such context, considering the high incidence of premature births and, consequently, the need for hospitalization in special healthcare, which may determine survival and recovery, the objective of this study was analyzing the factors related to prolonged hospitalization and death of premature newborns in a border region.

\section{METHOD}

\section{Design OF STUdY}

Cross-sectional study with retrospective data collection.

\section{LOCAL}

This is an analysis of the hospitalization of premature babies in the Neonatal Intensive Care Unit (NICU) and/ or the Neonatal Intermediate Care Unit (NIMCU) of a Brazilian municipality in the triple border of Brazil, Paraguay, and Argentina.

\section{Population}

Included children had a Gestational Age (GA) under 37 weeks and were hospitalized, regardless of the mother's origin. The population was thus composed of all premature children hospitalized in NICU and/or NIMCU from 01/01/2013 to $12 / 31 / 2017$.

\section{Data collection}

The search for information, conducted by two nurses with professional experience on neonatology, lasted from July 2017 to May 2018, in the files sector of the municipality's reference hospital for high-risk pregnancy and neonatology, with data from electronic medical records and register books. A structured script was used, with the independent variables organized into: i) maternal and obstetric data: maternal age, nationality, number of prenatal appointments, maternal intercurrences (during pregnancy and/or childbirth); ii) newborn data: GA, weight at birth, 1st and 5th minute Apgar index, baby's health complications; and the dependent variables: i) number of days of hospitalization; ii) outcome (discharge, death, or transference).

The information on maternal intercurrences included premature amniorrhexis, hypertensive syndromes, hemorrhages, infectious diseases, acute fetal distress, labor with no defined cause, metabolic, hematologic, respiratory, and urinary problems, hydramnios, cord prolapse, cervical insufficiency, and maternal uterine malformations. Complications with the premature baby's health included jaundice, infectious disorders, pulmonary, metabolic, cardiovascular, hematologic, cerebral, gastrointestinal, hemorrhagic, kidney, cutaneous, hepatic/vesicular, genitourinary, osseous/neuromuscular changes, and cardiopulmonary arrest.

\section{Data TREATMENT AND ANALYSIS}

The data were tabulated into Microsoft Excel $^{\circledR}$ spreadsheets and, for statistical analysis processing, they were imported into 
the programs IBM SPSS Statistics version 25 and R i386 version 3.4.0. Kolmogorov-Smirnov test was used to evaluate data normality. The variables maternal age, weight at birth, GA, 1st and 5th minute Apgar index, and duration of hospitalization of premature children were evaluated with Pearson Correlation. To compare the number of days of hospitalization among the response categories of the variables prenatal appointments $(<7$ and $\geq 7$ ), fifth minute Apgar ( $<7$ and $\geq 7$ ), residency in Brazil, maternal intercurrences and complications, Student's t test was used. To verify the association of the variable outcome (discharge, death, and transference grouped with discharge) with the variables residency in Brazil, maternal intercurrences, complications, and the categorized weight at birth, GA, 1st and 5th minute Apgar, the tests Pearson's Chi-squared or Fisher's Exact were used. In the statistical analysis, a significance level of $\alpha=0.05$ was adopted.

\section{ETHICAL ASPECTS}

This research was approved by the Research Ethics Committee of Universidade Estadual do Oeste do Paraná, in opinion number 2.009.310/2017, and observed Resolution
466/2012, by the National Health Council, on research with human subjects.

\section{RESULTS}

In the five-year period between 2013 and 2017, 21,429 children were born, $90.4 \%$ of which were born to Brazilian mothers, 2.5\% Brazilian mothers living in Paraguay, 4.7\% Paraguayan, 0.9\% Argentinian, and 1.5\% born to mothers of other nationalities (e.g., Lebanese, Chinese, Korean, Syrian). In the same period, 2,195 premature children were born, with a $10.3 \%$ incidence of premature births. Out of the premature babies, $43.3 \%$ required hospitalization in NICU or NIMCU, as shown in Table 1.

Regarding the association of occurrence of prematurity in children born in a border municipality and the mother's nationality, there was no statistically significant difference (Chi-squared $\mathrm{p}=0.1433$ ). The mother's nationality had no influence on the birth of premature children in the studied group. Likewise, the results related to the hospitalization of premature children and mother's nationality had no statistically significant difference (Chi-squared, $\mathrm{p}=0.5828$ ).

Table 1 - Distribution of births per prematurity and hospitalization of premature babies per mother's nationality between 2013 and 2017 - Foz do Iguaçu, PR, Brazil, 2019.

\begin{tabular}{|c|c|c|c|c|c|c|c|c|c|c|}
\hline \multirow{3}{*}{ Nationality } & \multicolumn{4}{|c|}{ Prematurity } & \multicolumn{5}{|c|}{ Hospitalized premature baby } & \multirow{3}{*}{$p^{*}$} \\
\hline & \multicolumn{2}{|c|}{ No } & \multicolumn{2}{|c|}{ Yes } & $p^{*}$ & \multicolumn{2}{|c|}{ No } & \multicolumn{2}{|c|}{ Yes } & \\
\hline & $\mathbf{n}$ & $\%$ & $\mathbf{n}$ & $\%$ & & $\mathbf{n}$ & $\%$ & $\mathbf{n}$ & $\%$ & \\
\hline Brazilian & 17392 & 90.4 & 1973 & 89.9 & & 1113 & 89.5 & 860 & 90.4 & \\
\hline Brazilian in Paraguay & 478 & 2.5 & 65 & 3.0 & & 41 & 3.3 & 24 & 2.5 & \\
\hline Paraguayan & 901 & 4.7 & 107 & 4.9 & & 65 & 5.2 & 42 & 4.4 & \\
\hline Argentinian & 175 & 0.9 & 27 & 1.2 & & 13 & 1.0 & 14 & 1.5 & \\
\hline Others & 288 & 1.5 & 23 & 1.0 & & 12 & 1.0 & 11 & 1.2 & \\
\hline Total & 19234 & 100 & 2195 & 100.0 & 0.1433 & 1244 & 100.0 & 951 & 100.0 & 0.5828 \\
\hline
\end{tabular}

* Chi-squared test for association, with a significance level of 0.05 .

By Pearson correlation, presented in Table 2, there was a strong correlation between weight and GA $(r=0.793)$ and 1 st and 5th minute Apgar ( $\mathrm{r}=0.781$ ). The observed correlations were moderate between the variables weight at birth and 1 st and 5th minute Apgar ( $r=0.320$ and $r=0.359)$ and GA and the 1st and 5th minute Apgar scores ( $\mathrm{r}=0.466$ and $\mathrm{r}=0.473)$. There is a moderate negative correlation between weight at birth and duration of hospitalization $(r=-0.302)$, indicating that higher weight implied fewer days of hospitalization. 
Table 2 - Pearson Correlation between maternal age, prenatal appointments, weight at birth, gestational age, 1st and 5th minute Apgar index, and duration of hospitalization of premature children hospitalized between 2013 and 2017 - Foz do Iguaçu, PR, Brazil, 2019.

\begin{tabular}{lcccc}
\hline Variables & $\mathbf{n}$ & $\mathbf{R}$ & $\mathrm{Cl} 95 \%$ & $\boldsymbol{p}$ \\
\hline Maternal age & & & & \\
Prenatal appointment & 920 & 0.122 & $(0.06 ; 0.19)$ & 0.000 \\
Weight at birth & 951 & 0.058 & $(-0.01 ; 0.12)$ & 0.074 \\
Gestational age & 951 & 0.085 & $(0.02 ; 0.15)$ & 0.009 \\
$\begin{array}{l}\text { 1st minute Apgar } \\
\text { 5th minute Apgar }\end{array}$ & 945 & 0.035 & $(0.03 ; 0.10)$ & 0.279 \\
Duration of hospitalization & 951 & 0.034 & $(-0.03 ; 0.10)$ & 0.301 \\
\hline
\end{tabular}

Prenatal appointments

\begin{tabular}{|c|c|c|c|c|}
\hline Weight at birth & 920 & 0.204 & $(0.14 ; 0.27)$ & 0.000 \\
\hline Gestational age & 920 & 0.238 & $(0.18 ; 0.30)$ & 0.000 \\
\hline 1st minute Apgar & 915 & 0.142 & $(0.08 ; 0.21)$ & 0.000 \\
\hline 5th minute Apgar & 915 & 0.159 & $(0.09 ; 0.22)$ & 0.000 \\
\hline Duration of hospitalization & 920 & -0.032 & $(-0.10 ; 0.03)$ & 0.329 \\
\hline
\end{tabular}

Weight at birth

\begin{tabular}{lcccc} 
Gestational age & 951 & 0.793 & $(0.77 ; 0.82)$ & 0.000 \\
1st minute Apgar & 945 & 0.320 & $(0.26 ; 0.38)$ & 0.000 \\
5th minute Apgar & 945 & 0.359 & $(0.30 ; 0.41)$ & 0.000 \\
Duration of hospitalization & 951 & -0.302 & $(-0.36 ;-0.24)$ & 0.000 \\
\hline
\end{tabular}

Gestational age

$\begin{array}{lrrrr}\text { 1st minute Apgar } & 945 & 0.466 & (0.41 ; 0.51) & 0.000 \\ \text { 5th minute Apgar } & 945 & 0.473 & (0.42 ; 0.52) & 0.000 \\ & & & & \\ \text { Duration of hospitalization } & 951 & -0.199 & (-0.26 ;-0.14) & 0.000\end{array}$

1st minute Apgar

$\begin{array}{lrrrr}\text { 5th minute Apgar } & 945 & 0.781 & (0.76 ; 0.81) & 0.000 \\ \text { Duration of hospitalization } & 945 & 0.004 & (-0.06 ; 0.07) & 0.901\end{array}$

5th minute Apgar

Duration of hospitalization $\quad 945 \quad 0.048 \quad(-0.02 ; 0.11) \quad 0.138$

In Table 3, the data show no statistically significant difference between the mean duration of hospitalization of premature children with mother residency in a foreign country and with the number of prenatal appointments. However, mothers who presented gestational intercurrences, Apgar index under seven in the 5 th minute of life, and complications with the premature baby showed a statistically significant difference, which suggests a prolonged duration of hospitalization in NICU for premature children.

Table 3 - Difference between the mean days of hospitalization of premature children hospitalized between 2013 and 2017, compared per mother's country of residence, number of prenatal appointments, maternal intercurrences, 5th minute Apgar index (discharge and death), and complications during hospitalization - Foz do Iguaçu, PR, Brazil, 2019.

\begin{tabular}{lccc}
\hline Variables & $\mathbf{n}$ & $\begin{array}{c}\text { Mean number of } \\
\text { days (SD) }\end{array}$ & $\boldsymbol{p}^{*}$ \\
\hline Mother living in Brazil & & & \\
Yes & 858 & $22.8 \pm 24.3$ & 0.248 \\
No & 92 & $25.9 \pm 25.5$ & \\
\hline
\end{tabular}

Prenatal appointments

\begin{tabular}{lccc}
$<7$ & 567 & $24.3 \pm 27.2$ & 0.091 \\
$\geq 7$ & 353 & $21.7 \pm 19.2$ & \\
\hline Maternal intercurrence & & & \\
Yes & 615 & $24.5 \pm 25.6$ & 0.013 \\
No & 336 & $20.4 \pm 22.0$ & \\
\hline
\end{tabular}

5th minute Apgar with discharge outcome

\begin{tabular}{lccc}
$<7$ & 37 & $40.3 \pm 34.5$ & 0.009 \\
$\geq 7$ & 709 & $24.6 \pm 23.8$ & \\
\hline
\end{tabular}

5th minute Apgar with death outcome

$\begin{array}{lccc}<7 & 67 & 4.8 \pm 10.0 & <0.001 \\ \geq 7 & 132 & 19.6 \pm 24.6 & \end{array}$

Complications during the hospitalization

\begin{tabular}{llll} 
Yes & 656 & $26.6 \pm 26.8$ & $<0.001$ \\
No & 295 & $15.4 \pm 16.0$ & \\
\hline
\end{tabular}

*Student's t test.

Concerning the outcome, a correlation between some factors was attempted at to verify potential risks of premature children progressing to in-hospital death, as shown in Table 4. The outcome in-hospital death occurred for $21.3 \%$ of the studied children and did not correlate with maternal foreign residency or with the presence of maternal intercurrences. However, lower weight at birth, extreme prematurity, Apgar index lower than seven in the 1st and 5th minute and the 
presence of clinical complications were correlated to the outcome death during hospitalization.

Table 4 - Relation between mother's residence area, maternal intercurrence, weight at birth, gestational age, Apgar index in the 1st and 5th minutes, and complications during hospitalization with a discharge or death outcome in premature children hospitalized between 2013 and 2017 - Foz do Iguaçu, PR, Brazil, 2019.

\begin{tabular}{lccccc}
\hline \multirow{2}{*}{ Variables } & \multicolumn{2}{c}{ Discharge } & \multicolumn{2}{c}{ Death } & \multirow{2}{*}{$\boldsymbol{P}$} \\
\cline { 2 - 5 } & $\mathbf{n}$ & $\%$ & $\mathbf{n}$ & $\%$ & \\
\hline Residence in Brazil & & & & & \\
Yes & 673 & 78.4 & 185 & 21.6 & $0.492^{*}$ \\
No & 75 & 81.5 & 17 & 18.5 & \\
\hline Maternal intercurrence & & & & & \\
Yes & 490 & 79.7 & 125 & 20.3 & \\
No & 259 & 77.1 & 77 & 22.9 & $0.350^{*}$ \\
\hline
\end{tabular}

\begin{tabular}{lccccc}
\hline Weight at birth & & & & & \\
Up to 1,000 g & 32 & 22.4 & 111 & 77.6 & \\
$1,001-1,500 \mathrm{~g}$ & 152 & 74.5 & 52 & 25.5 & \\
$1,501-2,499 \mathrm{~g}$ & 478 & 94.5 & 28 & 5.5 & $<0.001^{* *}$ \\
$2,500-3,999 \mathrm{~g}$ & 84 & 88.4 & 11 & 11.6 & \\
4,000 g or more & 03 & 100.0 & 00 & 0.0 & \\
\hline Gestational age & & & & & \\
$<28$ weeks & 28 & 22.2 & 98 & 77.8 & \\
28 - 31 weeks & 172 & 73.8 & 61 & 26.2 & \\
32 - 33 weeks & 261 & 93.2 & 19 & 6.8 & $<0.001^{*}$ \\
34 - 36 weeks & 288 & 92.3 & 24 & 7.7 & \\
\hline
\end{tabular}

1st minute Apgar

\begin{tabular}{cccccc}
$<7$ & 213 & 61.0 & 136 & 39.0 & \\
$\geq 7$ & 533 & 89.4 & 63 & 10.6 & $<0.001 *$ \\
\hline
\end{tabular}

5th minute Apgar

\begin{tabular}{cccccc}
$<7$ & 37 & 35.6 & 67 & 64.4 & \\
$\geq 7$ & 709 & 84.3 & 132 & 15.7 & $<0.001^{*}$ \\
\hline
\end{tabular}

Complications during hospitalization

\begin{tabular}{cccccc} 
Yes & 482 & 73.5 & 174 & 26.5 & \\
No & 267 & 90.5 & 28 & 9.5 & $<0.001 *$ \\
\hline
\end{tabular}

${ }^{*}$ Chi-squared test. ${ }^{* *}$ Fisher's Exact test.

\section{DISCUSSION}

The results show that care of foreigners was more representative for Brazilians living in Paraguay and Paraguayans. A study identified the reason for these women to seek the Brazilian health services, which is related to the precariousness of the Paraguayan health system of the Eastern border, differently from that of Argentina ${ }^{(12)}$. Women living in Paraguay who seek more often the local Brazilian health services are young, with greater parity, lower education, and no partner ${ }^{(12)}$.

Prematurity was not higher among foreigners; however, it is worth reflecting on the problem of health services of border municipalities and how individuals living near these regions use the available health systems. Border regions are influenced by population mobility, which weakens the healthcare system in structural, economic, and human aspects, as well as organizational approaches to care ${ }^{(12-13)}$.Thus, a fragile mother and infant healthcare system may collaborate with the increase of prematurity rates and their complications, directly impacting children's morbidity and mortality in these regions.

The aggravating factor of this path is related to late search for health care by this population: usually women search for health services only in the moment of childbirth, and do not always receive prenatal care. This results in the birth conditions of premature babies and, consequently, the need for intensive therapy hospitalization, which was high in this study (43.3\%) when compared to a study conducted in Southern Brazil, whose rate was $28.8 \%{ }^{(14)}$.

In an attempt to revert such situations, the Brazilian government, by means of a resource of SIS-Fronteira, instituted in 2007 the Mother and Child Center in Foz do Iguaçu, with the objective of providing care to Brazilian pregnant women living in Paraguay during all of pregnancy and postpartum. However, for foreign pregnant women, prenatal care is still incipient, which poses a challenge to health managers in the border region ${ }^{(12)}$. This program is no longer active and the Mother and Child Center which provides medical and nursing care in prenatal and in the follow-up of child growth and development, especially of premature children, is maintained with resources of the municipality of Foz do Iguaçu. This shows the intense need for cooperation between countries to ensure access to public health services to the cross-border population, helping municipality managers to elaborate strategies and search for integration of these regions to improve their population's health ${ }^{(13)}$.

A European study has identified that the migrant flow between European states and non-European countries is pointed as a risk factor for prematurity ${ }^{(15)}$. However, such study has verified that the associations with prematurity depend on spontaneous birth, origin, reference groups used for comparison, duration of residency, and on the reasons for migration, due to these being refugees or economic migrants $^{(15-16)}$.

In this research, maternal age higher than 35 years was important for prenatal follow-up. The prenatal appointments work as a protective factor for the newborn, given that proper care during this period prevents premature birth, its complications, and, specially, child death ${ }^{(4)}$. It also enables the early identification and prevention of harmful intercurrences, reducing long-term risks and damage ${ }^{(17)}$. However, such actions may become fragile in vulnerable regions, such as this study's location.

Also, higher weight at birth, GA, and better Apgar indexes were verified to reduce the duration of hospitalization. A Brazilian study has found the same correlation between weight, GA, and duration of hospitalization ${ }^{(18)}$. According to a study conducted in Detroit-USA, although moderately and late premature children present better conditions at birth and during hospitalization, special attention should be paid in their care, given that there is a growing understanding that these children are at risk of long and short-term morbidities, with potential damage to neurological development and higher risk of death in the first year of life ${ }^{(19)}$. Thus, the rationale for long-term specialized 
follow-up is important and, although late prematurity is not considered high-risk, nurses should consider during follow-up appointments their singular needs for a healthy growth and development regarding nutrition and neurological, cognitive, and behavioral maturation ${ }^{(10,19)}$.

Gestational intercurrences, Apgar scores lower than seven in the 5 th minute of life, and the presence of complications in the clinical conditions of premature babies identified in this research suggest a prolonged duration of hospitalization in NICU. Studies on maternal intercurrences show that complications during pregnancy may both favor prematurity or increase the duration of hospitalization ${ }^{(20-22)}$,emphasizing that, given the mother's clinical instabilities, the fetus may be distressed and receive fewer nutrients and oxygen for surviving and adapting to the extrauterine environment.

The need for interventions in the delivery room in face of Apgar lower than seven may both increase duration of hospitalization of premature babies or potentialize risk of death ${ }^{(3,23-24)}$. In this context, understanding the variables that contribute to increasing duration of hospitalization enables the organization of timely and preventive interventions, with an efficient performance of health professionals in the pregnancy period, labor, and birth. Such interventions may and should encompass family care - given that their relations are shaken with prematurity and prolonged hospitalization, increasing the risk of abuse, violence, and negligence - , considering it as primordial and determinant for the children's favorable progress and life prognosis, with necessities of sheltering, support, and appropriate orientation for their exercise of parental roles ${ }^{(3)}$.

Also of importance is the relation between prolonged hospitalization and the repercussions for premature children's growth and development. To follow up premature newborns, it is fundamental to understand the individual history of each child, considering the duration of hospitalization, the received stimuli, and their family environment, as well as long-term results for neurological, cardiovascular, and metabolic development ${ }^{(25)}$. In this context, the nurse takes various attributions, responsibilities, technical dexterity, and skills which are indispensable to safely identify, evaluate, understand, and support newborns and their families during the critical period of hospitalization and in long-term health follow-up ${ }^{(10)}$.

Similarly to a study conducted in Saudi Arabia, this study's findings correlate weight at birth and GA with death: the smallest and more premature the baby, the higher are the chances for progression to this outcome ${ }^{(26)}$. Another study conducted in a NICU in South Korea has also shown the relation between a smaller GA, low Apgar indexes in the 1st and 5 th minute, and higher chances of death ${ }^{(23)}$. Such study also indicates the need for cardiopulmonary resuscitation in the delivery room and being born to a foreign mother as factors which favor in-hospital death ${ }^{(23)}$.

In developed countries, such as England and Wales, a study pointed out that most premature babies (82\%) were classified as moderately and late premature; the highest risk of death was identified among babies with a GA lower than 32 weeks $^{(27)}$, which shows the disparities among research results in different places. In this research, moderately and late premature babies amounted to slightly over $60 \%$ and there was a correlation between lower weight and GA with the outcome in-hospital death.

This investigation's results suggest that care and management of labor and delivery may have been crucial for an unfavorable outcome for the child, given that, when there is no risk of death, premature labor must be conducted to delay birth closer to the term, creating an opportunity for administration of medication that potentialize pulmonary maturation and makes the premature be born with better weight and good vitality, represented by better Apgar scores. Also, the conducts in neonatal care must advocate care which avoids complications, such as sepsis, cardiac, hemorrhagic, and pulmonary changes, which might determine the premature child's survival.

In the studied triple border region, where healthcare is aggravated by the overcharge of health services and other sectors due to the presence of a fluctuating population, which becomes three times higher ${ }^{(12-13)}$, mother and child health may be compromised, although living in a different country was not shown to be statistically significant. The access of the population to public health services is a process with instabilities and discontinuities, in which scarcity of resources is still a limiting factor and health actions occur in emergency situations with little health surveillance ${ }^{(13)}$.

A study has shown that border regions are presented as areas in which many women omit where they live during the search for healthcare due to concerns that they will not receive the same care offered to Brazilians, or because their right to an appointment was denied, leading to a late search for prenatal care, with harmful consequences to the mother's and the baby's health ${ }^{(12)}$.

In this context, the adaptations to seek healthcare also create high costs for the border municipality, especially due to the lack of information related to the pregnancy and reproductive record, which may increase the likelihood of complications, the chances of performing surgical births, and long hospitalization of woman and child ${ }^{(12)}$.

Considering the obtained results and their implications for the practice, the gaps in structure and public policies for the border region in the Paraguayan healthcare system are noteworthy. These endanger the population requiring prenatal care and the referral of mothers-to-be to safe deliveries, given that this process is currently unilateral. This research is expected to foster the debate with political authorities of the triple border through broadening work groups, integrating health professionals and managers of these countries, and promoting exchange of experiences between them to strengthen public policies with joint participation, discussion, and decision-making.

Prematurity persists as an important public health problem, with substantial consequences, as it corroborates higher morbidity and mortality rates and, on the long-term, compromising sensory, neuropsychomotor, and cognitive development of premature children ${ }^{(26)}$. Also, prematurity may lead to family stress and financial costs for families and the State ${ }^{(3,5,28)}$, which increasingly indicates the need for preventing premature birth, establishing it as one of the priorities of services and health managers around the world. 
As limitations of this investigation, the factors of long hospitalization and death of premature newborns in a municipality of the triple border are emphasized. The fact that these results might vary with the inclusion of data from the other municipalities, Puerto Iguazú (Argentina) and Ciudad del Este (Paraguay), is reckoned. Also, this is met with limitations, considering the possible incompleteness of medical records data used in the retrospective collection.

\section{CONCLUSION}

Premature birth was similar between Brazilian and foreign women. Gestational intercurrences, Apgar scores lower than seven in the 5 th minute of life, and presence of complications in the clinical condition of premature children were correlated to a prolonged period of hospitalization; lower weight at birth, extreme prematurity, Apgar index lower than seven in the 1st and 5th minute, and the baby's clinical complications were correlated to the death outcome.

The complications are present throughout the duration of the premature child's hospitalization, with efforts to overcome the unfavorable outcome and face the challenges of sequels which may emerge after discharge and throughout life. To advance the integration between countries and their respective border municipalities, such as the studied location, valuing healthcare processes, with strategic investments in technological, human, and structural resources, is a notorious condition.

\section{RESUMO}

Objetivo: Analisar fatores relacionados à hospitalização prolongada e ao óbito de recém-nascidos prematuros em uma região de fronteira. Método: Estudo transversal, com coleta retrospectiva de dados, que analisou 951 prontuários de prematuros hospitalizados entre 2013 e 2017. As variáveis independentes foram idade materna, nacionalidade, consultas de pré-natal, intercorrências maternas, idade gestacional, peso ao nascer, Apgar, complicações; as variáveis dependentes foram dias de hospitalização, alta, óbito e transferência. Foram utilizados os testes Qui-quadrado de Pearson e Exato de Fisher. Resultados: O nascimento prematuro representou 10,3\%; destes, 43,3\% foram hospitalizados. A prevalência da mortalidade foi 21,3\%. Poucas consultas de pré-natal, intercorrências maternas, Apgar de $5^{\circ}$ minuto baixo e complicações da saúde do bebê aumentaram os dias de hospitalização. Menor peso e idade gestacional, Apgar baixo e complicações com o bebê aumentaram o óbito. Conclusão: Conhecer aspectos da hospitalização permitiu identificar fatores que desencadeiam complicações ao prematuro, relevantes aos esforços para superar os desfechos desfavoráveis e enfrentar desafios das sequelas ao longo da vida. A integração entre países e suas fronteiras torna-se condição notória para acelerar processos assistenciais e proporcionar melhores desfechos.

\section{DESCRITORES}

Recém-Nascido Prematuro; Hospitalização; Morte; Enfermagem Neonatal; Saúde na Fronteira.

\section{RESUMEN}

Objetivo: Analizar los factores relacionados con la hospitalización prolongada y la defunción de los recién nacidos prematuros en una región fronteriza. Método: Estudio transversal, con recogida de datos retrospectiva, en el que se analizaron 951 historias clínicas de bebés prematuros hospitalizados entre 2013 y 2017. Las variables independientes fueron la edad materna, la nacionalidad, las consultas prenatales, las intercurrencias de las madres, la edad gestacional, el peso al nacer, Apgar y las complicaciones; las variables dependientes fueron los días de hospitalización, el alta, la defunción y el traslado. Se utilizaron las pruebas Chi-cuadrado de Pearson y Exacto de Fisher. Resultados: Los nacimientos prematuros representaron el 10,3\%, de los cuales el 43,3\% fueron hospitalizados. La prevalencia de mortalidad fue del 21,3\%. Pocas consultas prenatales, las intercurrencias maternas, el Apgar bajo a los 5 minutos y las complicaciones de salud del bebé aumentaron los días de hospitalización. El peso y la edad gestacional más bajos, el Apgar bajo y las complicaciones con el bebé aumentaron la mortalidad. Conclusión: Conocer los aspectos de la hospitalización permitió identificar los factores que desencadenan complicaciones en los bebés prematuros, relevantes para los esfuerzos por superar los resultados desfavorables y enfrentar los desafíos de las secuelas a lo largo de la vida. La integración entre los países y sus fronteras es una condición notoria para acelerar los procesos de asistencia y proporcionar mejores resultados.

\section{DESCRIPTORES}

Recien Nacido Prematuro; Hospitalización; Muerte; Enfermería Neonatal; Salud Fronteiriza.

\section{REFERENCES}

1. Monangi NK, Brockway HM, House M, Zhang G, Muglia LJ. The genetics of preterm birth: progress and promise. Semin Perinatol. 2015;39(8):574-83. doi: http://dx.doi.org/10.1053/j.semperi.2015.09.005

2. World Health Organization. Preterm birth [Internet]. Geneva: WHO; 2018 [cited 2019 May 15]. Available from: http://www.who.int/ news-room/fact-sheets/detail/preterm-birth

3. Sociedade Brasileira de Pediatria; Departamento Científico de Neonatologia. Prevenção da prematuridade: uma intervenção da gestão e da assistência. Documento Científico n.2 [Internet]. São Paulo SBP; 2017 [citado 2019 maio 15]. Disponível em: https://portaldeboaspraticas. iff.fiocruz.br/wp-content/uploads/2017/11/Prevencaodaprematuridade.pdf

4. Garcia LP, Fernandes CM, Traebert J. Risk factors for neonatal death in the capital city with the lowest infant mortality rate in Brazil. J Pediatr (Rio J). 2019;95(2):194-200. doi: http://dx.doi.org/10.1016/j.jped.2017.12.007

5. Damian A, Waterkemper R, Paludo CA. Perfil de neonatos internados em unidade de tratamento intensivo neonatal: estudo transversal. Arq Ciênc Saúde. 2016;23(2):100-5. doi: https://doi.org/10.17696/2318-3691.23.2.2016.308

6. Marcuartú AC, Malveira SS. Perfil de recém-nascidos prematuros de muito baixo peso internados em unidade de cuidados intensivos neonatais. Rev Bras Ciênc Saúde. 2017; 21(1):5-10. doi: https://doi.org/10.22478/ufpb.2317-6032.2017v21n1.28551 
7. Sousa DS, Sousa Junior AS, Santos ADR, Melo EV, Lima SO, Almeida-Santos MA, et al. Morbidade em recém-nascidos prematuros de extremo baixo peso em unidade de terapia intensiva neonatal. Rev Bras Saúde Mat Inf. 2017;17(1):149-57. doi: http://dx.doi. org/10.1590/1806-93042017000100008

8. Lee M, Wu K, Yu A, Roumiantsev S, Shailam R, Nimkin K1, Sagar P1. Pulmonary hemorrhage in neonatal respiratory distress syndrome: radiographic evolution, course, complications and long-term clinical outcomes. J Neonatal Perinatal Med. 2019;12(2):161-71. doi: http:// dx.doi.org/10.3233/NPM-1867

9. Ryan M, Lacaze-Masmonteil T, Mohammad K. Neuroprotection from acute brain injury in preterm infants. Paediatr Child Health. 2019;24(4):276-90. doi: http://dx.doi.org/10.1093/pch/pxz056

10. Silveira A, Neves ET. Vulnerabilidade das crianças com necessidades especiais de saúde: implicações para a enfermagem. Rev Gaúcha Enferm. 2012;33(4):172-80. doi: http://dx.doi.org/10.1590/S1983-14472012000400022

11. Silva RMM, Lui AM, Correio TZHO, Arcoverde MA, Meira MCR, Cardoso LL. Busca ativa de crianças com necessidades especiais de saúde na comunidade: relato de experiência. Rev Enferm UFSM. 2015;5(1):178-85. doi: http://dx.doi.org/10.5902/2179769213024

12. Mello F, Victora CG, Gonçalves H. Saúde nas fronteiras: análise quantitativa e qualitativa da clientela do Centro Materno Infantil de Foz do Iguaçu, Brasil. Ciênc Saúde Coletiva. 2015;20(7):2135-45. doi: http://dx.doi.org/10.1590/1413-81232015207.09462014

13. Aikes S, Rizzotto MLF. Integração regional em cidades gêmeas do Paraná, Brasil, no âmbito da saúde. Cad Saúde Pública. 2018;34(8):e00182117. doi: http://dx.doi.org/10.1590/0102-311x00182117

14. Tabile PM, Teixeira RM, Toso G, Matras RC, Fuhmann IM, Pires MC, et al. Características dos partos pré-termo em hospital de ensino do interior do sul do Brasil: análise de 6 anos. Rev AMRGS. 2016;60(3):168-72.

15. Delnord M, Blondel B, Zeitilin J. What contributes to disparities in the preterm birth rate in European countries? Curr Opin Obstet Gynecol. 2015;27(2):133-42. doi: http://dx.doi.org/10.1097/GCO.0000000000000156

16. Sorbye IK, Daltveit AK, Sundby J, Vangen S. Preterm subtypes by immigrants' length of residence in Norway: a population-based study. BMC Pregnancy Childbirth. 2014;14(1):1-14. doi: http://dx.doi.org/10.1186/1471-2393-14-239

17. Mazzoni SE, Carter EB. Group prenatal care. Am J Obstetr Gynecol. 2017;216(6):552-6. doi: http://dx.doi.org/10.1016/j.ajog.2017.02.006

18. Arrué AM, Neves ET, Silveira A, Pieszak GM. Caracterização da morbimortalidade de recém-nascidos internados em unidade de terapia intensiva neonatal. Rev Enferm UFSM. 2013;3(1):86-92. doi: http://dx.doi.org/10.5902/217976925947

19. Natarajan G, Shankaran S. Short and long-term outcomes of moderate and late preterm infants. Am J Perinatol. 2016;33(3):305-17. doi: http://dx.doi.org/10.1055/s-0035-1571150

20. Barros FC, Papageorghiou AT, Victora CG, Noble JA, Pang R, lams J, et al. The distribution of clinical phenotypes of preterm birth syndrome: implications for prevention. JAMA Pediatr. 2015;169(3):220-9. doi: http://dx.doi.org/10.1001/jamapediatrics.2014.3040

21. Jelliffe-Pawlowski LL, Baer RJ, Blumenfeld YJ, Ryckman KK, O’Brodovich HM, Gould JB, et al. Maternal characteristics and mid-pregnancy serum biomarkers as risk factors for subtypes of preterm birth. BJOG. 2015;122(11):1484-93. doi: http://dx.doi.org/10.1111/14710528.13495

22. lams JD, Romero R, Creasy RK. Preterm labor and birth. In: Resnik R, Lockwood CJ, Moore T, Greene MF, Copel J, Silver RM. Creasy \& resnick's maternal e fetal medicine: principles and practice. Philadelphia: Elsevier; 2018. p. 545-82

23. Lim JW, Chung SH, Kang DR, Kim CR. Risk factors for cause-specifc mortality of very-low-birth weight infants in the korean neonatal network. J Korean Med Sc. 2015;30 Suppl:35-44. doi: http://dx.doi.org/10.3346/jkms.2015.30.S1.S35

24. Demitto MO, Gravena AAF, Dell'Agnolo CM, Antunes MB, Pelloso SM. High risk pregnancies and factors associated with neonatal death. Rev Esc Enferm USP. 2017;51:e03208. doi: http://dx.doi.org/10.1590/s1980-220x2016127103208

25. Silveira RC, Procianoy RS. Preterm newborn's postnatal growth patterns: how to evaluate them. J Pediatr (Rio J). 2019;95 Suppl 1:42-8. doi: http://dx.doi.org/10.1016/j.jped.2018.10.006

26. Al-Qurashi FO, Abdullah AY, Awary BH. Epidemiological aspects of prematurity in the Eastern region of Saudi Arabia. Saudi Med J. 2016;37(4):414-9. doi: http://dx.doi.org10.15537/smj.2016.4.14309

27. Platt MJ. Outcomes in preterm infants. Publlic Health. 2014;128(5):399-403. doi: http://dx.doi.org/24794180

28. Frey HÁ, Klebanoff MA. The epidemiology, etiology, and costs of preterm birth. Semin Fetal Neonatal Med. 2016;21(2):68-73. doi: http:// dx.doi.org/10.1016/j.siny.2015.12.011 